\title{
MiéRT KÉNE SZABÁLYOZNI AZ ÁRNYÉKOKTATÁST?
}

\author{
HARSÁNYI PÉTER
}

ELTE TáTK Szociológia Doktori Iskola

Mark Bray \& Ora Kwo: Regulating Private Tutoring for Public Good: Policy Options for Supplementary Education in Asia. Hong Kong, 2014. Comparative Education Research Centre. $x+93$ p. ISBN 9789881785299

1963 őszén jelent meg a Család és Iskola hasábjain Kontra György biológiatanár cikke a tanulók egyre szaporodó, tanórákon kívüli elfoglaltságairól. „Külön nyelvi órák, karének, hangszer és szolfézs, népitánc, vagy balett, külön torna, sportiskola, szakkör (esetleg szabályellenesen nem is egy), önképzőkör, úttörö-, vagy KISZ-foglalkozás - és mégcsak nem is soroltam fel valamennyit. Ki szólhatna külön-külön akármelyik program ellen egyetlen rossz szót is? Valamenynyi nagyszerü alkalom gyerekeink sokoldalú képzésére - ha egyenként nézzük. De épp a jó tanuló, kiváló gyerekek napjaiban nem egyenként, hanem együtt jelentkezik két-három vagy még több belölük. Az orvosságra szokták mondani, hogy kis adagban gyógyit, nagy adagban mérgez. Így van ez valahogy a különórákkal is." ${ }^{1}$ Azóta eltelt ötvenhét év, a diákok közel fele ${ }^{2}$ részben saját fejlődése, részben a vizsgakövetelményeknek való megfelelés érdekében változatlanul jár iskolán kívüli különórákra. A helyzet azonban egyenlőtlen: minél nagyobb városban, minél jobb anyagi körülmények között él valaki, annál nagyobb eséllyel vesz részt ilyen foglalkozáson. ${ }^{3}$

\footnotetext{
Kontra Gy. (1963) Különóra. Család és Iskola, Vol. 14. No. 11. p. 19.

2 Tomasz Gábor szóbeli közlése.

3 Nagr M. (2003) Tanulók, munkaterheik és iskolai eredményességük. Iskolakultúra, Vol. 13. No. 1. pp. 48-50.
}

$\mathrm{Ez}$ a tendencia a legtöbb országban megfigyelhető, és nincs ez másképp a nemzetközi összehasonlító felméréseken mindig kiemelten jól teljesítő távol-keleti államokban sem. Míg azonban Kínában, Japánban és Dél-Koreában a magánoktatás szigorúan szabályozott terület, addig ez máshol csak részben, vagy egyáltalán nincs így. Mark Bray és Ora Kwo, a Hongkongi Egyetem két tanára ebben a 2014-ben megjelent munkában arra keresi a választ, hogy Ázsia országai milyen módszerekkel szabályozzák a magánoktatás szektorát, valamint hogy a közjó, a társadalmi-gazdasági fejlődés érdekében miért is érdemes a hivatalos, állami rendszeren kívüli árnyékoktatást törvényileg kontrollálni.

$\mathrm{A} z$ első fejezet az ázsiai országokban folyó magánoktatás nagyságrendjét mutatja be. Ebben a sok és sokféle adattal megtámogatott részben államonkénti bontásban láthatjuk, hogy eltérő mértékben ugyan, de mindegyik vizsgált országban jelen van az állami melletti árnyékoktatás (míg egyes észak-indiai tartományokban ez a tanulóknak csupán a 3\%-át érinti, addig például Szingapúrban 97\%-ukat). Általánosan elmondható az is, hogy mindegyik országban azokból a tárgyakból vesznek leginkább különórát a diákok, amelyekből később vizsgázniuk is kell: matematikából, természettudományokból, angol és nemzeti nyelvből. A legtöbb országban 
nagy különbségek mutatkoznak e téren az általános- és középiskolások között (utóbbiaknál gyakoribb), valamint a vidékiek és a városiak között. Míg Pakisztánban például a fövárosi diákoknak 60,2\%-a, a Karacsin kívülieknek alig több mint tizede részesül magánoktatásban.

A vizsgálati körbe bevont ázsiai országok azonban nem rendelkeznek annyi közös tulajdonsággal, hogy egy elemzési egységként szerepeljenek. Örményországtól kezdve Makaón át a Brunei Szultánságig - ez egy földrajzi szempontból hatalmas, kulturális szempontból pedig korántsem összefüggő terület. Ráadásul a könyv legnagyobb hiányossága - a szerzők pedig magyarázattal sem szolgálnak rá -, hogy Oroszország és a közel-keleti államok jórészt mind kimaradtak a kötetből, és így olyan országok hiányoznak, mint Törökország, Afganisztán, Irak, Szaúd-Arábia vagy Izrael.

A jelenlegi helyzet ismertetése után a következő fejezet arra a kérdésre igyekszik választ adni, hogy miért is kéne az államoknak szabályozniuk a magánoktatást, hiszen az látszólag nem tartozik a hatáskörükbe. A szerzőpáros mérsékelt szociáldemokrata meggyőződése szerint az állam feladata, hogy a területén folytatott minden oktatási tevékenységet kontroll alatt tudjon, és így felelössége van abban, hogy minden polgára minőségi oktatáshoz jusson. Bray és Kwo érvelésének öt pillére van:

1. Az oktatás általában véve csökkentheti az egyenlötlenségeket. Az állami szabályozás segíthet abban, hogy az alacsonyabb jövedelműek, lányok, kisebbséghez tartozók és vidéken élők jobb minőségű magánoktatásban részesüljenek. Bár a szerzők elismerik, hogy ezt kifejezetten nehéz szabályozással elérni, és az egyenlőtlenségeknek is csupán a mértékét tudják csökkenteni, felszámolni nem tudják. Ezért arra ösztökélik a döntéshozókat, hogy vizsgálják felül a hatályban lévő jogi kereteket, ismerjék meg a nemzetközi példákat és törekedjenek a jó minták átvételére. Ezt Bray és Kwo nem győzi eleget hangsúlyozni, e minták ismertetése a könyv tulajdonképpeni célja.

2. A magánoktatás rossz hatással lehet az állami oktatásra. Megfigyelhető például, hogy a formális és informális oktatásban egyaránt dolgozó tanár a tanórán direkt nem ad át bizonyos ismereteket, hogy azokat az iskolán kívüli korrepetáláson, külön összeg fejében tegye meg. Ezek a tanárok a magánoktatásba több energiát is fektetnek, ami az állami iskolában zajló munka rovására megy. A szerzők szerint ez a diákok oldaláról is tetten érhető: jobban tisztelik a magántanárt, mert az nem ingyen oktatja őket, így az állami rendszer tekintélye tovább csorbul.

3. A magánoktatás a korrupció melegágya. Akárhonnan is nézzük, az, ha egy tanár direkt nem ad át valamilyen ismeretet tanórán, hanem csak különórán, pénzért, az bizony korrupciónak számít. Bray és Kwo szerint azért van kiemelt felelössége ebben az ügyben az államnak, mert az itt felmerülö korrupciónak pont azok a fiatalok vannak kitéve, akiknek erkölcsi érzéke ekkor fejlődik ki. Fontos azonban, hogy az állam legyen megértő és tanúsítson figyelmet a helyi sajátosságok iránt is, hiszen országonként eltérő, hogy egy ilyen kényes helyzetben mi az, ami belefér, és mi az, ami nem. Jellemzö, hogy a szülők elsősorban nem is a szolgáltatást nyújtó tanárokat, hanem a mérgező környezetet hibáztatják az ehhez hasonló helyzetek kialakulása miatt.

4. Fogyasztók és alkalmazottak védelme. Ez nyilvánvalóan nem az egyedül dolgozó magántanárokat, hanem elsősorban a nem állami szférába tartozó iskolákat 
és azok dolgozóit érinti. Mivel e szolgáltatások (vagyis a megszerzett tudás) értékét meghatározni rettentő nehéz, a szülőket gyakran átverik, ráadásul az iskolák hirdetései is félrevezetők lehetnek. Sokszor az ott dolgozó tanárok is kiszolgáltatott helyzetben vannak. Előfordul, hogy a cégek egyáltalán nem, vagy csak részben jelentik be őket.

5. A magánoktatás szabályozása komoly adóbevételekkel járhat. A szerzők szerint a magántanároktól elvárható, hogy szolgáltatásaik után adót fizessenek. Hogy az állam milyen nagy bevételre tehet szert ezáltal, érzékelteti, hogy Dél-Koreában az árnyékoktatás GDPrészesedése 3\% körüli. A tanárok ellenkezése természetesen várható, azonban - jegyzi meg Bray és Kwo - sok országban egyenesen kitüntetésnek vennék az oktatók, ha az állam különböző adók kiszabásával ismerné el tevékenységük fontosságát. Kár, hogy ezt a magyar fülnek meghökkentő feltételezést a szerzők adatokkal nem támasztják alá.

Ez volt tehát az öt fö érv a magánoktatás minél szélesebb körű állami szabályozása mellett. Az utolsó két fejezet a szabályozandó szereplőket mutatja be, és a döntéshozóknak szolgál praktikus tanácsokkal.

Ázsiában kimondottan népszerűek a különböző tanfolyamokat indító oktatási cégek, ahol egy-egy órán akár több száz diák is részt vesz egyszerre. A szerzők azt tanácsolják, hogy a kormányok ezeket a vállalatokat kötelezzék regisztrációra, valamint arra, hogy hozzák nyilvánosságra oktatási terveiket, pontos tarifáikat, a nekik dolgozó tanárok névsorát és pedagógiai tapasztalatait. Sokféle szabályozási minta figyelhető meg erre vonatkozóan. Kínában minden ilyen szolgáltatást nyújtó szervezetnek külön igazgatótanácsa van, mely szigorú jelentési kötelezettséggel bír a központi szervek felé. Malajziában ugyanazt a tantervet kell követniük, mint az állami iskoláknak. A Fülöp-szigeteken pedig az ilyen vállalatok minden téren ugyanolyan besorolás alá esnek, mint bármilyen más gazdasági társaság. DélKoreában tapasztalható a legrészletesebb állami kontroll: nagyon pontos szabályok vonatkoznak a hirdetésekre, nyitvatartási időre, a tanárok megfelelő végzettségére és oktatói tapasztalatára.

A magánoktatás következő szabályozandó szereplöi azok a tanárok, akik a formális és informális oktatásban egyaránt részt vesznek. Indiában, Japánban, Dél-Koreában és Kína egyes tartományaiban például ez eleve tilos, máshol vagy engedélyhez kötik (pl. Vietnamban és Malajziában), vagy egyáltalán nem szabályozzák (pl. a Fülöp-szigeteken és Thaiföldön). A magánórákat adó egyetemi hallgatók helyzete Dél-Koreát kivéve egyik országban sincsen törvényi keretek közé foglalva. Az elmúlt évtizedben óriási mértékben nőtt az interneten keresztül nyújtott különórák száma is, ami felveti a fokozott óvatosság kérdését, illetve azt, hogy lehetséges-e egyáltalán eredményesen szabályozás alá vonni egy ehhez hasonlóan képlékeny és dinamikus szektort.

Az utolsó fejezet a szabályozások végrehajtásával kapcsolatban szolgálhatna hasznos és igazán megszívlelendő tanácsokkal a döntéshozók számára, de sajnos inkább csak jóindulatú közhelyeket olvashatunk: járjanak el körültekintően, egyeztessenek az érintett szereplőkkel és tájékoztassák őket, növeljék a fogyasztói tudatosságot, figyeljenek a jogsértésekre, legyenek nyitottak a panaszkezelésre, valamint segítsék elő a szülők és tanulók helyes döntését. Érdekes szempont viszont, hogy Bray és Kwo szerint az államnak minden erejével arra kell törekednie, hogy elősegítse a szektor önszabályozását - törvényi lépésekre csak akkor van szükség, ha az önkontroll nem valósul meg. Pozitív 
példaként említik az Ausztrál Magánoktatási Egyesület (Australian Tutoring Association - ATA) és a Japán Juku Egyesület (Japanese Juku Association - JJA) tevékenységét, melyek útmutatásai nemzetközi standarddá váltak, és a minőségi magánoktatás alapját jelenthetik.

Végezetül szeretném hazai kontextusba helyezni a magánoktatás regulációjának témáját. E terület Magyarországon teljesen szabályozatlan. Nem vonatkozik rá semmiféle jogszabály, csupán a Közoktatásról szóló 1993. évi LXXIX. törvény nyolcadik fejezetében találunk arra vonatkozó rendelkezést, hogy egy iskola pedagógiai programja szerint megtartott órákra és szakkörökre hivatkozva nem kérhet pénzt. ${ }^{4}$ Ezt leszámítva bárki annyi és olyan különórát adhat, amennyit akar. Illetve a magánórák szabályos idejét befolyásolhatja az is, hogy a diákok kötelesek 16 óráig iskolájuk felügyelete alatt lenni, ${ }^{5}$ vagyis jogszerüen csak utána vehetnek részt olyan foglalkozáson, amit nem az adott intézmény szervez. Mayer József, az (egykori) OFI munkatársa 2013-ban úgy érvelt az egész napos iskola mellett, hogy míg „a középosztályba tartozó gyerekeknek

\footnotetext{
4 1993. évi LXXIX. tv. 114.\$

5 2011. évi CXC. tv. $46 . \S$
}

megvan a lehetöségük, hogy piaci alapon, különórák formájában szerezzék meg a versenyképességet, a személyiségük gazdagitását", addig „vannak olyan családok, abol ezt nem tudják megadni a gyermeknek. Mi az egész napos iskolával mindenki számára biztositani akarjuk a versenyképességet, a minöséget." $^{6} \mathrm{~A} z$ egész napos iskola integrációs potenciálja ellenére azonban nem érte el ezt a célját, mivel a tanulók felmentést kérhetnek alóla, és így a középosztályi gyerekek ugyanúgy részt vehetnek az informális oktatás különóráin, mint előtte.

Bray és Kwo könyve kiváló és gondos gyüjteménye számos ázsiai ország magánoktatást szabályozó szakpolitikáinak, ráadásul tanácsait szociálisan érzékeny, a gazdasági és társadalmi egyenlőséget valló módon sikerül átadnia. Fájó hiányossága, hogy az elemzésbe bevont országok köre nem teljes, ez pedig mindvégig reflektálatlan marad. Kitüzött célját azonban eléri, hiszen a döntéshozók számára hasznos és praktikus példákkal szolgál. Érdekes olvasmánya lehet annak, akit érdekel az oktatáspolitika, az árnyékoktatás, valamint az összehasonlító pedagógia területe.

6 Stöckert-Kozák A. (2013) Egész napos iskola, a lehetőségek iskolája. (Interjú Kőpatakiné Mészáros Máriával és Mayer Józseffel.) Ujj Köznevelés, Vol. 69. No. 9. pp. 11-12.

A cikk a Creative Commons Attribution 4.0 International License (https://creativecommons.org/licenses/ by-nc/4.0/) feltételei szerint publikált Open Access közlemény, melynek szellemében a cikk bármilyen médiumban szabadon felhasználható, megosztható és újraközölhető, feltéve, hogy az eredeti szerző és a közlés helye, illetve a CC License linkje és az esetlegesen végrehajtott módosítások feltüntetésre kerülnek. 